\title{
THE TRANSITION LABOR MARKET- COMPETITIVENESS OF THE EMPLOYEE
}

\author{
Venelin Terziev \\ Academician of the Russian Academy of Natural History, Moscow, Russia, \\ Prof. D.Sc. (Ec.), D.Sc. (National Security), D.Sc. (Social Activities), Ph.D., National Military \\ University, Veliko Tarnovo, Bulgaria; University of Rousse, Rousse, Bulgaria, terziev@skmat.com

\begin{abstract}
The problems of the modern labor market are subject to increasing interest in the field of research, policy discussions and management practice. They become especially topical in the years of transition and the membership of Bulgaria in the European Union, as well as the emerging new challenges facing Bulgaria in the new demographic, economic and social conditions.
\end{abstract}

Keywords: employment, unemployment, employers, labor market.

\section{INTRODUCTION}

The significant differences in the competitiveness of the employees may lead to a delay in the selection or to the lack of perspectives in the demand as a whole. On the other hand, the shortage of labor force with the necessary qualifications, leads to an increase of the period of occupation of job vacancies.

Under a policy aimed at improving the organization and functioning of the labor market, in order to reduce the period of job search and occupy job vacancies mainly through preferable impact on the internal factors, we will mean a policy on the labor market.

Even the well-organized and flexible labor market is strongly influenced by other factors that are beyond the segment considered by us, which create obstacles and hamper their effective functioning. The properly functioning labor market, which faces such factors, sends signals to the external environment and accepts signals thereof. The reading of the signals sent by the labor market and the timely and adequate response to these signals is a responsibility of the external environment.

\section{COMPETITIVENESS OF THE EMPLOYEE}

The diversity and the level of influence of the external factors on the labor market is extremely large. We do not aim at giving a detailed analysis and assessment of their impact. We will mention as an example such external factors determining the inflow of labor force on the labor market, such as demographic movement of the population, its composition, economic activity, the intensity of the labor transfers.

On the other hand, of crucial importance for the labor market are the economic factors (e.g. the dynamics of the GDP, the phases of the business cycle, the investment activity, etc.) and the labor factors (salaries, 
working time, practice of hiring and dismissal, social partnership). An essential role is also played by the quality of the labor force, the conformity of the structure of the labor force with the structure of the job positions (in professions and sectors, training features, geographically), etc.

From the entire diversity of factors that have an external influence on the labor market, we will further restrict ourselves to the illustration of part of them only, which will allow us to demonstrate the breadth and diversity of the factors that have impact, and on the other hand, to identify more accurately those factors that are directly related to the internal mechanism of "functioning" of the labor market.

In the process of the complex market restructuring of the Bulgarian economy, carried out by the end of the 80-s, specific temporary factors are generated and activated. At first, they impede the growth, cause deterioration and even individual deformations in some key macroeconomic relationships and proportions. With the progress of the reforms, the asymmetric projections are increasingly limited, as far as the conditions of growth in the country gradually recover and improve after the reduction in the intensity of the denationalization and privatization, trade and price liberalization, reforms in the agricultural sector. The effect of the determined by the transition factors is differentiated in the period before and after $1997-1998$ and stimulate the interest for integral analysis of the main macroeconomic dependencies throughout the entire period of transition (Georgiev, 2016; Georgiev, 2017-a).

In practice, there is a direct dependence between the economic growth and the unemployment during the period of transition in Bulgaria.

The theory of the labor economics - science that studies the behavior of the employees and the employers in the field of work - is well developed for the market economy, although constantly evolving. The developments in this field are well known and accessible today, including in the form of educational materials. There are a number of major developments devoted to the modern theory of unemployment and its relationship with the macroeconomic dynamics. Indeed, many of the theoretical aspects, confirmed by the practice of the western economies, are difficult to use in the conditions of the transition period in Bulgaria. The famous Phillips curve, for example, does not describe the situation in the Bulgarian economy in the early $90-\mathrm{s}$, probably due to ultra-high inflation. For the traditional market economies, the natural response by the employers upon the reduction of the volume of production or the excessive salary growth is to reduce the demand for labor and to lay off employees. In our economy, the reaction is different - the excessive labor force, representing the production factor "labor" predominantly remains in the working team. The other classic positions of the theory of the labor market, employment and unemployment can find confirmation only based on a long enough statistical history of the economy. This applies, for example, for the cyclical fluctuations and the short-term and long-term measures for their equalization, related to them. Unfortunately, there is no theory of the functioning of the labor markets under conditions of systematic transformation of the economic system, both in foreign and among Bulgarian sources.

Nevertheless, in parallel with the formation of the new economic system and its development on its own basis in Bulgaria, the postulates and laws for the functioning of the labor market will find confirmation more often. The same pertains also to the means of achieving equilibrium on the labor market.

Considering the above, we have used only the theoretical basis that is a result of the collective experience of many countries, applicable in many respects or at least useful to us.

It is obvious, that the economic situation has the decisive external influence on the labor market, employment and unemployment: the more job positions are generated and the more they meet the labor force supply, the better perspectives for employment are to be found, the better the labor markets functions. We might say that the creation of more job positions is the main alternative to unemployment.

The main hope here before was related to the actions of the Government. However, in the new economic conditions the direct influence on this process by the Government is limited by its budgetary resources (financing of government services, "budget-dependent" sector of the economy, funds for investment purposes, etc.). Given the relatively small size of these resources, the budget deficit and the restrictions on tax increases, job positions are created mainly in the private sector. The Government indirectly influences the process of job creation, through implementation of the macroeconomic policy. This policy plays a dual role in reducing the unemployment. Firstly, it can help to limit the cyclical fluctuations in the production and employment. Secondly, it creates a basis for improving the investment climate in the non-budgetary sector, based on sustainable financial system and price stability. In general, the government's macro-task can be formulated as follows: maintaining stable employment, economic growth that allows this, stable consumer prices to maintain and improve standards of living and a balanced budget (strong external balance of payments). The imbalance is one of the parts of the "balance equation", leading to instability of the remaining parts. That is why it is not possible permanent employment to be achieved only through policy measures in 
the labor market, but on the other hand, without this policy the balance is impossible (Terziev, Kanev, 2019; Terziev, 2019a-k).

Even in a perfectly organized labor market where the state conducts an effective policy, the job positions can decrease under the influence of external economic factors.

On the other hand, the macroeconomic development is a necessary condition for increasing the job positions and the employment. However, such an increase is always limited as a result of macroeconomic measures.

Let us consider in details the relationship between the main economic indicators and employment. The economic growth expressed in the dynamics of the GDP can be "expanded" into several components, expressed by the formula:

$$
G D P=\frac{\text { Employed }}{L F} \times \frac{G D P}{\text { Employed }} \times L F
$$

LF - labor force

The formula proves that the GDP depends on the changes in the level of employment, labor productivity and the dynamics of the labor force.

Table 1. presents the dynamics of the GDP, employment and labor productivity in the period of economic recession in some countries. Compared with periods of crises in other countries in the last decade, a few differences are noticed in Bulgaria. In the first place, the scale of the reduction of the economic indicators in Bulgaria is much more significant than in other countries. Moreover, their dynamics does not necessarily acquire a negative meaning and may be accompanied by a reduction in the growth indicators. In the second place, the periods of decline in production are significantly shorter than the duration of the recession in the Bulgarian economy. In the third place, unlike Bulgaria, where a simultaneous decrease in the GDP, the employment and the labor productivity are noticed, the latter is under less pressure under the conditions of a "normal" market economy or, as opposed to reducing the growth rate of the GDP, increases. These differences undoubtedly reveal the specifics of the crisis under the conditions of transition. We believe that, in order to clarify the specific reaction of the transition economy against the macroeconomic changes, it is useful to examine what the behavior of these two indicators would be, if the Bulgarian economy was a "normal" market economy.

Table 1. Economic growth and its components (in \%\% for the previous year)

\begin{tabular}{|c|c|c|c|c|c|c|}
\hline & 1990 & 1991 & 1992 & 1993 & 1994 & 1995 \\
\hline \multicolumn{7}{|l|}{ USA } \\
\hline GDP & 0.8 & -1.2 & 2.6 & 3.0 & 4.0 & 3.0 \\
\hline Level of employment & -0.3 & -1.3 & -0.7 & 0.7 & 0.6 & 0.5 \\
\hline Productivity & 0.3 & -0.3 & 2.0 & 1.5 & 0.8 & 1.2 \\
\hline Labor force & 0.8 & 0.4 & 1.3 & 0.8 & 2.6 & 1.3 \\
\hline \multicolumn{7}{|l|}{ Japan } \\
\hline GDP & 4.8 & 4.0 & 1.1. & 1.0 & 0.8 & 2.7 \\
\hline Employment rate & 0.19 & -0.01 & -0.1 & -0.4 & -0.4 & 0.1 \\
\hline Productivity & 2.7 & 2.0 & 0.1 & 0.8 & 0.5 & 1.8 \\
\hline Labor force & 1.8 & 1.9 & 1.1 & 0.6 & 0.7 & 0.8 \\
\hline \multicolumn{7}{|l|}{ Finland } \\
\hline GDP & 0.3 & 6.4 & -3.8 & -2.6 & 1.9 & 4.7 \\
\hline
\end{tabular}


IJASOS- International E-Journal of Advances in Social Sciences, Vol. V, Issue 14, August 2019

\begin{tabular}{|c|c|c|c|c|c|c|}
\hline & 1990 & 1991 & 1992 & 1993 & 1994 & 1995 \\
\hline Employment rate & -0.0 & -4.3 & -5.9 & -5.4 & -0.8 & 1.1 \\
\hline Productivity & 0.4 & 12.2 & 3.6 & 3.7 & 2.8 & 3.3 \\
\hline Labor force & -0.1 & -0.9 & -1.2 & -0.7 & -0.1 & 0.3 \\
\hline \multicolumn{7}{|l|}{ Ireland } \\
\hline GDP & 8.2 & 2.2 & 4.9 & 2.3 & 4.1 & 4.5 \\
\hline Employment rate & 2.3 & -2.4 & -0.7 & -0.3 & 1.1 & 0.3 \\
\hline Productivity & 4.6 & 2.7 & 3.1 & 1.2 & 2.1 & 3.0 \\
\hline Labor force & 1.1 & 2.0 & 2.5 & 1.4 & 0.9 & 1.2 \\
\hline \multicolumn{7}{|l|}{ Sweden } \\
\hline GDP & 1.4 & -1.7 & -1.9 & -2.1 & 2.7 & 2.9 \\
\hline Employment rate & -0.6 & -1.2 & -1.8 & -3.1 & 0.2 & 0.3 \\
\hline Productivity & 0.5 & -0.01 & 0.9 & 3.4 & 3.4 & 2.0 \\
\hline Labor force & 1.6 & -0.5 & -1.0 & -2.3 & -0.9 & 0.6 \\
\hline
\end{tabular}

The decline in production is usually accompanied by the formation of a relative surplus of labor force, as for the production of a smaller volume production (services) fewer employees are required and therefore fewer job positions.

If in the phase of decline in production economically unjustified job positions are cut in order to maintain the productivity (or to retain its decline), at lower production volumes the working hours fund is reduced in order to maintain the competitiveness of the enterprise. Part of the workforce is laid off and another part is switched to "underemployment" mode, i.e. is forced to work part time due to economic reasons. Either way, the total average number of employees is reduced to the ""economically determined" or "effective demand". The subsequent improvement in the market situation after the recession leads to increased economic activity, increased production volumes, increased the overall demand for labor force.

If in the reduction of the volumes of the GDP the surplus of the labor force does not decline (the practice to prevent the dismissal of staff dominates), the productivity of labor is reduced, and as a result, the salary goes down as well. The number of employees does not reach the size of the economically determined demand. The surplus of labor force remains in production, the volumes of "underemployment" grow. The costs of the employers in relation to the excessive workforce retain the recovery of the productivity and economic improvement.

In general, the relationship between the employment, the dynamics of the GDP and the labor productivity can be expressed by the following formula:

$$
N E t+1=N E t \times \frac{\Delta G P D t+1}{\Delta L P t+1}
$$

where

$\mathrm{NEt}+1$ - number of employed during the current year $t+1$;

$\mathrm{NEt}$ - number of employed in the previous year $\mathrm{t}$;

$\Delta$ GDP $\mathrm{t}+1$ - gross domestic product in the current year in $\%$ over the previous year;

$\Delta \mathrm{LP} t+1$ - labor productivity in the current year \% over the previous year. 
If in the reduction of the GDP, the labor productivity does not go down, then the number of employees decline to a number corresponding to the "economically determined demand". The difference between the economically active population and the "economically determined" demand is the "excessive labor force". Moreover, the volume of the "excessive" labor force generally corresponds to the volume of the open unemployment. If in the same dynamics of the GDP, the labor productivity goes down as well, then the difference between the number of gainfully employed and the "economically determined demand" represents the quantity "economically unjustified employment", generated directly in the production.

Liberal scenario: transformation of the workforce In the development of the situation in Bulgaria, according to "purely liberal economic rules" after the reduction of the production volumes, the Bulgarian employers (perhaps with some delay) would response with lay-off of the excess workforce, i.e. lay-off of employees in order to recover the productivity. The actual lay-off of workforce to fully offset the reduced productivity, would lead to a redistribution of the workforce between those who have complete and economically justifiable jobs, corresponding to the "economically determined demand," and the unemployed. The unemployment rate would reach $30-35 \%$ of the economically active population. The actual loss of personnel potential in order to avoid the decline in productivity for many companies (especially where the number of staff is determined by the technological process) would rather lead to economic downturn, than to recovery of the profitability. In the short term, it would be impossible to create an adequate number of new effective jobs to compensate the loss of jobs. In order to reduce the unemployment for several years, while maintaining the level of productivity of labor, a GDP growth of $30-40 \%$ per year would be necessary. However, such an assumption is unrealistic.

If we use the "inflationary" analogy, then this path would lead not only to the transformation of the "oppressed" unemployment in an open form, but also to "hyper unemployment". Its socio-economic consequences would most likely be worse than the consequences of over hyperinflation.

Conservative scenario: retaining the employment. The scenario of retention of full employment in a period of economic recession and the period of restructuring of the Bulgarian economy, would only change the ratio between gainful and formal employment.

If employment would remain stable, the number of the unemployed would be determined by its initial volume and the growth of the economically active population, i.e. by the unsatisfied demand for jobs by those entering into labor force.

Potential jobs would be vacated for the unemployed at the expense of the natural leaving of employees. The unemployment rate would have fluctuated within 1.5-2.5\%. However, the labor productivity would decline for the period 1991-1996 1,5 times. This would mean that the employment would be largely formal. The job positions for the employees would be retained. However, due to the economically unjustified huge labor costs for labor force, the employment other than the "normal" one would reach unrealistic absolute values. Consequently, this would lead to reduction of the salaries, as the fund for remuneration of employees would be distributed among a larger number of employees, or would result in a delay of payments in an even larger scale, while maintaining the previous rates. The restructuring of the economy would be virtually impossible, and the exit from the recession even more complicated. The need for structural and other changes would in spite of all lead to a return to the question on transferring of employees from declining industries. By analogy, the situation would be similar to the "repressed" inflation before the reform.

Real scenario: reaction of the employment to the systematic changes.

In practice, the events deviated from the theoretical trajectories. In Bulgaria in 1992-1996, the volume of the GDP goes down.

Most job positions in the "new" sector of the economy are occupied to a greater degree rather by those who have jobs, than the unemployed. They occupy the new job positions, transferring from the old ones, and do not include in the involuntary unemployed. The majority of the unemployed occupy job positions mainly in the "traditional" sector of the economy and not in the "new" one (Terziev, 2018-d; Terziev, Georgiev, 2018e-f).

In general, the job cuts prevail over the opening of new jobs. As a result, the compensating creation of new jobs seems to be insufficient. The prevailing tendency of a general reduction of the employment, especially in the traditional enterprises, remains. However, this is not related to the actual mass reduction. If an enterprise is faced with the need to reduce the salary fund, only small part of the employees are subject to compulsory lay-off. The others start seeking new jobs and find it rather by transferring than by unemployment. This part of the employees who remain employed, are not able to change their jobs due to lack of alternative jobs (and in many cases due to lack of required profession, qualification), or rely on a quick recovery of the enterprise. The expectation of stabilization is accompanied by the emergence of large-scale underemployment and the 
so-called "hidden" unemployment. The latter turns into a unique form of "extreme flexibility" of the Bulgarian labor market. In the basis of such an "extreme flexibility" lies the high differentiation of the salary, its low level for the majority of the employees, long delays in payment of salaries, reduced working hours, including those related to the administrative leaves, etc. Such manifestations of flexibility turn into the price that the economy of Bulgaria pays for the low level of open unemployment. In the first years of the reform, it remains at a level much lower than expected. Its volumes give way to the dimension of the hidden in the productivity compulsory underemployment.

With certain reservations, the deviation of the "economically set scenario" from the real scenario characterizes the marginal volumes of the "excessive" labor force accumulated during the decline in the production volumes. The employees have only one job in the taxable sector of the economy with a regular working day (week). The productivity of their labor is not lower than the level during the year before the reduction of the volumes of production, and they receive the regular salary corresponding to the results of the work performed. At the same time, the status of a relatively large amount of people can be described as an "excessive" labor force. This characterizes the increasing unemployment rate. The other have employment, but different from the "regular" employment, due to economic reasons. Some of them fall under the conventional definition compulsory part-time employment.

Unfortunately, the official statistics do not fix the exact distribution of employees according to the modes of employment. There are no data on the number of voluntary occupied job positions with reduced working hours (voluntary part-time employment), on the compulsory and constantly working on such jobs, as well as on those who have temporary irregular employment. The studies conducted by the National Employment Service (later Employment Agency) and the National Statistical Institute, fix only one group of employees, usually working in full mode, but temporarily working part-time or on leave after an initiative by the management (i.e. for economic reasons).

The compulsory underemployment is a common phenomenon in the world practice as well, especially in times of economic crises. However, the dimensions of part-time employment are generally less significant. For example, in Sweden in 1991 - a total of $5.3 \%$ of all employees on compulsory employment work part time, in the USA - 4\% in Ireland - slightly more than $3 \%$. In this case, the practice of part working time is common, i.e. the employers agree with the employees to preserve their job positions, but to reduce their working time fund and accordingly their salaries. In general, a group of employees is reduced in accordance with the improvement of the economic situation, if the reasons that cause the "underemployment" are not related to the lack or shortage of the qualification required or other "external" economic factors. Despite the negative attitude towards these facts, the underemployment is seen as a temporary alternative to open unemployment, allowing the employee to maintain contact with the employer and the labor market, with the work habits, and consequently, to have a better chance to return to full employment compared with those who are fully unemployed.

What distinguishes the Bulgarian labor market is the presence of a relatively large amount of "extra" or formally employed workers who would rather lose their jobs in a period of normal cyclical crisis in the normal market economy. We can assume that it is namely this part of the labor force that is in an intermediate state between the employment and the unemployment, due to systematic violation of the economic relations, which lead to unprecedented changes in the structure of demand.

These employees can retain their status for a long period of time or can be under a real threat of dismissal. Alternatively, depending on the economic and other circumstances, they can become part of those who have "normal" employment or are unemployed.

The ratio between the number of the real unemployed and the employed who have retained employment other than the "normal" employment, is for example 1 to 2 and characterizes the "dominance" of the internal production labor problems on the problem of the open unemployment. This situation is unique in the world practice.

This is regarded as a more significant source of social tension than the open unemployment.

The unrealized threat of switching from "potential unemployment" in its open form, as well as the relatively low indicators of its official level, form the attitude to this problem as a problem of low public importance.

In the period 1992-1997, a situation of a partially "suppressed" unemployment is formed on the labor market, which has become one of the major phenomena of the period of transition. The ultra-radical measures during this period would lead to "hyper unemployment" and probably to even more profound social crisis. In addition, the insufficient detection of the unemployment shifted the focus of the labor issues from the usual for the period of economic recession issues for neutralization of the open unemployment, in direction of the 
internal production labor issues related to the phenomenon of "underemployment". This phenomenon, unlike the commonly spread part-time employment due to a cyclical decline in production, has a slightly different character.

The problem of "underemployment", caused by the systemic crisis cannot be solved by simply activating the layoff of the employees and by transferring of the unemployed to new jobs. In the first place, some of the employees are employed in potentially profitable industries. In addition, the ability of today's economy to generate enough new jobs is highly questionable. The "underemployment" will have a significant impact on both the dynamics of employment and unemployment in a period of economic recovery and the rate of actual recovery.

Under which possible trajectories could the GDP, the employment and the labor productivity after the economic upturn in Bulgaria be modified? The increase of the production, as a rule, is not accompanied by a simultaneous and adequate expansion of the hiring of new employees. The transition from increase of the production to increase of the employment depends on the growth of the labor productivity. The productivity changes pro-cyclically. It decreases at the beginning during the recession due to the surplus of labor force and increases during the upturn, as the employers seek to increase at first the working time fund of the hired employees (in particular, to eliminate the "underemployment" in production), and only then to hire new employees. Therefore, the employment growth generally follows the growth of the aggregate demand with a certain delay. Furthermore, the unemployment rate may be increased as long as the mode of economic recovery is not definitively established. Moreover, the greater the deviation of the number of employees from the value of the effective demand (internal production reserves in the form of "underemployment"), the more limited the opportunities to increase the employment at the expense of hiring of new employees.

We will try to analyze the possible scenarios for the dynamics of employment and unemployment according to the changes in the GDP and the productivity after the start of the economic recovery. This will make two assumptions. Firstly, we will consider 1998 as the beginning of the recovery. Secondly, we will determine the period for exit of the target benchmarks for seven years, i.e. it will correspond to a period that is approximately equal to the preceding period of recession.

Scenario 1: recovery of the productivity level and the number of employees from 1991. One of the tasks during the period of economic recovery could be formulated as an immediate recovery of the level of labor productivity, employment and growth in the GDP to indicators corresponding to the year preceding the recession. As we consider the possibilities of stabilization of the employment and unemployment, we will formulate the goal in another way: what are the necessary pace of the GDP growth to recover the appropriate level of productivity and employed population?

In terms of combating unemployment, this scenario seems very attractive. The labor productivity goes up almost 1.5 times until 2005. The employers, after an increase in the demand for labor force, optimize the working time fund. The phenomenon of "hidden unemployment" practically disappears. The further increase of the demand for labor force leads to an increase of the additionally hired employees. The number of the employees reaches the size of the effective demand. The unemployment rate decreases from $8 \%$ (for the economically active population) in 1997 to $5 \%$ in 2005 . Accordingly, the minimum costs associated with the payment of unemployment benefits are reduced in half. However, such changes are possible only in case of increase of the GDP over seven years by 1.6 times, i.e. at an average annual growth of $5-8 \%$ in a period of maximum "warm up" of the economy. Obviously, such assumptions are too optimistic. The dynamics of the GDP will be rather smooth, with annual growth rates, gradually increasing from $1 \%$ at the beginning of the period of recovery to $5 \%$ after the period. Due to these limitations, the simultaneous recovery of the number of employed population and the productivity levels in 2005 seems unrealistic.

Scenario 2: recovery of the productivity level in 1991 with moderate GDP growth. The recovery of the labor productivity of the Bulgarian enterprises to the level prior to the recession, creates potential possibilities of expansion of the aggregate demand for labor force, in accordance with the increase in the production volumes. However, given the volume of "underemployment" generated, the employers will seek in the first place to streamline the working time fund of the employees. In this case, if the increase in productivity faces with limited opportunities for transfer of the "underemployed" in a mode of regular employment, the employers can resort to lay-offs. With the expansion of production and exhaustion of the internal opportunities to increase the working time fund, the additional recruitment of labor force will increase.

According to the assumptions made, the total demand for labor force will decline. The open unemployment will increase at the expense of the partial lay-off of employees and the contraction of recruitment of new employees in the phase of upturn, and can reach about $20 \%$ of the economically active population. The phenomenon of "hidden unemployment" would be neutralized. However, the prospects for employment 
growth are found outside this period. One of the worst consequences of such a development is the accumulation of long-term unemployment, which reacts sluggishly to the improving employment opportunities.

In fact, this scenario is one of the options of the so-called "recovery without new jobs" in which the economic growth is provided at the expense of activation of factors, replacing the need for new labor force and preventing the total employment growth.

The more widely spread the phenomenon of "hidden unemployment" and accordingly, the bigger the opportunities to expand production and increase labor productivity at the expense of the increased efficiency of the personnel available, the less opportunities for additional recruitment of labor force and the more likely the "recovery" without new jobs.

Scenario 3: labor productivity growth that does not reduce the employment in a moderate pace of economic growth. Is it possible to have a development where the growth of the labor productivity is maintained, the "underemployment" is gradually eliminated and the employment opportunities do not get worse?

The scenario of the labor productivity growth that does not reduce the employment in a moderate pace of economic growth - in its implementation, the GDP volume will recover to $80 \%$ of the level in 1991 , the number of the employed population will gradually increase, but will fall behind the productivity growth, especially in the first three - four years of recovery (the meeting of the demand for labor force at the expense of the increase of the working time fund of the employed will have a certain impact). Indeed, due to the changes in the economically active population, the labor demand will be weaker than the supply. Moreover, the unemployment will increase to the point that the increased demand for labor force will absorb the additional demand for the population for work. The unemployment rate, before starting to decline, will exceed the performance of the previous years.

Scenario 4: stagnation. Each of the preceding scenarios is based on optimistic assumptions about the beginning of an economic growth. However, today there are more and more doubts in this regard. It is quite possible for the Bulgarian economy, despite some signs of growth, to "freeze" between the crisis in the past and the recovery in the future. The changes in the GDP may fluctuate around $1 \%$ on an annual basis and the positive changes in the labor productivity may prove to be sluggish. It is clear that in this case the creation of new jobs is problematic. The struggle of many of the employers for economic survival will push them to optimize the number of employees, in order to resist the loss of productivity. Tens of hundreds of jobs will be threatened with closure. The number of unemployed will increase and the unemployment rate may reach 20 $25 \%$. The prevention of lay-offs during this period will lead to reduction in the productivity and increase of the "underemployment", while at the same time the unemployment will increase.

The financial crisis that starts in August 1998 "postponed" for an indefinite time the beginning of the economic growth. According to some estimates, the loss of the GDP reaches 8-10\%. Obviously, its consequences for the labor market will have a negative impact for a long period of time. In addition, the possible scenarios for future developments remain in force, but from a different perspective.

Nevertheless, the means of the macroeconomic policy are able to impact positively on the unemployment caused by the economic recession and the general decrease in the demand for labor force. However, the pace at which the increase of the employment follows the economic recovery depends not only on the macro-economic situation, but on other factors of institutional, structural and other nature as well. As a whole, the use of instruments to influence the demand and supply of labor force can extend significantly those narrow spaces on the labor market that prevent the achieving of equilibrium. Since most of these measures are not directly connected with the policy of the labor market, we will make only a brief overview of some factors that impede the achieving of equilibrium.

The parameters of the labor supply are determined primarily by the dynamics of demography, the migratory movement of population and the socio-economic factors.

Thus, the pressure by the young people who first enter the labor market in search of work, could exceed the volume of the generated jobs, would complicate not only "the problem of finding a first job", but also reduce the potential possibilities for the unemployed to return to employment.

The period of recession, i.e. the first half of the 90-s coincides with the phase of reducing the growth of the population of working age. However, in the coming years "the demographic wave" will be characterized by an opposite trend. During the period 1997 - 2000, the active population will increase with relatively small quantities per year, which will create additional pressure on the labor market by increasing the aggregate demand for jobs. This "non-economic" factor may delay the increase of employment to a later period, to 
intensify the problem of finding a first job for the young people that enter the labor market for the first time, to increase the competition between younger and older generations.

The data characterizes the options of impact of the dynamics of the labor force on the employment. If in Bulgaria, as noted, the reduction of the labor force during the recession mitigate the problems of the labor market, then, for example, in the USA, Japan and Ireland the crisis "coincides" with the period of growth of the economically active population.

Of essential importance is also the possibility of transferring employees from sectors in which the number of employees shrinks, into expanding sectors of the economy. Moreover, the employment opportunities are greater if more jobs are created in the sectors that increase the number of jobs. In recent years, the traditional sectors (industry, construction, agriculture, etc.) are characterized by sustained negative balance between recruitment and lay-off of employees. The compensating increase in the number of jobs in sectors such as lending, finance, insurance, general business, etc. proves to be insufficient.

We might say that in recent years in Bulgaria sectors of the economy are formed, which differ significantly in terms of security and employment perspectives.

Firstly, these are mainly manufacturing sectors (industry, construction, agriculture, etc.), which concentrate over $70 \%$ of employees, but reduce their number. In this group of sectors, over $50 \%$ of all job vacancies are concentrated. It is true that the biggest problems related to regular payment of salaries, as well as a widespread underemployment are namely here.

Secondly, this is mainly the budgetary sector (including education, healthcare, government, etc.). It remains the most conservative and stable. The intensity of employment and lay-off is too moderate, and the number of job vacancies remains sensitive. It is clear that the budget sector remains the least risky in terms of potential possible loss of work, but those who work in this sector remain losers in terms of level and frequency of payment for their labor.

Thirdly, these are such new sectors, such as general business, finance, etc. The intensity of employment (the ratio of the employed persons in relation to the number of employees) in organizations operating with real estate is quite high. With regard to the financial status of the employees, this sector is in a better position than the industry, for example. The high level of job rotation of personnel proves that the employment for the employees of this kind of activity has a short-term nature. In general, this group of sectors does not play a significant role on the labor market. The number of the employed here is less than $1 \%$ of all employees, and the share of the job vacancies - $3 \%$ of the total number. Obviously, the relocation of employees here is also associated with the relatively short life cycle of the enterprises and the so-called "idle" of labor force.

As a result of the relatively low capacity of the new sectors of the labor market, able to accumulate labor force, and also as a result of the significant differences in the "user properties" of the jobs available here, the opportunities for restructuring of the employment shrink and relatively isolated sectoral labor markets are "preserved". As a result, the transfer of the employees takes place mainly within "their" segment of the labor market. The instability of employment in some segments, expressed in the reduction of the average duration of employment at the last job, leads to an increase of the "idle" of the labor force, strengthens the competition for jobs between the employees who change their jobs and the unemployed who seek to occupy them. Moreover, the unemployed are in general in a worse position. The existing conservatism in the budgetary segment, which provides a relatively constant employment but experiences underfunding and periodic lay-offs, also ceases to be an island of stability and for the time being cannot be considered as one of the factors that stabilizes the employment (as it is often considered in other countries).

Additional risk factor that may complicate the employment problem is the continuing high share of employees in large enterprises. A typical feature of the regional division of labor in the economy is the presence of industrial complexes located in the relatively large industrial centers, as well as the creation of cities with monoeconomic structure where one - two enterprises are fundamental. This leads to limited diversity of the production and therefore to increased vulnerability to external cataclysms and changes in the demand structure.

The strong dependence of the local labor markets on the economic situation of such large enterprises could lead to a critical situation, primarily in towns and villages. The major industrial centers have much more opportunities for relocation of the laid off employees. The towns fall in a hard and difficult to solve situation as a stoppage threatens not only the main production, but also the majority of the social infrastructure, which is normally supported by the monopolies on the labor market (Terziev, 2015-b).

The shift of the focus of the economic structure in the direction of small and medium-sized enterprises is a powerful factor of diversification of the employment opportunities. Given the limited opportunities to stabilize 
the employment in the majority of enterprises in the traditional sectors, obviously it is namely the small and medium-sized enterprises that are able to contribute substantially to this process.

Although the progress in the development of the small enterprises is noticeable, their compensating role in the creation of job positions not that large so far, but it can be activated. The positive role of the small businesses on the labor market can be expanded by a number of typical measures to overcome the obstacles in starting a new business, simplification of the rules that set limits to private initiatives, facilitating the access to credits, technical information and technological know-how, subcontracting programs with large companies, etc.

There are also many other reasons that may prevent the effective functioning of the labor market. More parttime job positions than "normal" job positions can be created. Such situation occurs if companies from sectors that use more actively flexible modes of labor (e.g. in the sector of services) are in a phase of progress. Generally, the positive trend of the economic recovery may still complicate the relocation of employees from the manufacturing industries, reducing the number of their employees and using traditionally male workforce in a normal working time.

The job positions generated by the economy may prove to be less paid. Such job positions can meet the existing demand for low-skilled workers. However, on the other hand, such situation may be in contradiction with the qualification structure of demand for jobs, reduce the opportunities for career development of the employed persons, and in the long run may increase the possibility of repeated unemployment.

The job positions created that require high qualifications in relatively new areas (e.g. financial sector), are at risk to be unoccupied due to lack of suitable labor force in the labor market. As a result, a "qualification gap" appears that maintains the growth of the employment and slows down the economic growth.

Apart from the effects of other factors, the less the barriers to hiring employees are, the more jobs will be created. One of the possible limiting factors is the high labor costs, not related to the salary (such as payments at the expense of the employers in the state social funds). Such costs may lead to a considerable difference between the cost of hiring of an employee by an employer and the salary that the employee receives. This difference that goes beyond certain limits, restricts the employment of employees and thus increases the unemployment, if the salary is not reduced in such a way as to offset the high taxes that the employer pays.

In addition to the barriers in hiring employees, obstacles on the commodities and service markets may also worsen the structural unemployment. For example, the insufficient competition on such markets allows companies to restrict production and to maintain high prices, thereby limiting the demand for labor force as well.

The removal of the above and other barriers increases the ability of the economy to generate productive and well-paid jobs and helps the reduction of the unemployment. However, at the same time people should be able to occupy the new job positions. It is not surprising that one of the reasons of the structural unemployment is the gap between the pressure on the labor force by the economy to adapt to changes and the ability of the employees for such adaptation. The lack of adaptation may turn almost into a main reason of preserving and increasing the unemployment, especially the long-term unemployment, even in the presence of job vacancies, both in times of economic recession and upturn.

Thus, unlike the traditional labor markets, responsive to the reduced demand by increasing unemployment, in the Bulgarian economy in transition a major group of employees in a transitional state between employed and unemployed is formed. The frictional unemployment (related to changing of the workplace) increases gradually, but in terms of scale, it obviously losses from the other forms of unemployment. The structural and cyclical unemployment can be characterized as a systemic unemployment caused by continuous and prolonged economic recession, stable imbalances in the economy, the lack of noticeable effect to compensate the loss of jobs in the industries with a shrunk production, the differences between the branches, regions, sectors of the economy. It is obvious that without accumulation of positive macroeconomic dynamics it is impossible to resolve the problems of unemployment (Terziev, Arabska, 2014; Terziev, 2015-b; Terziev, Arabska, 2016a).

The presence of both macroeconomic and other restrictions and barriers has a retaining effect on reducing the unemployment and increasing the employment even in times of economic recovery. The hopes for automatic improvement of the functioning of the labor market in a favorable macroeconomic dynamics seem however too optimistic. At present, there are no grounds to believe that the problem of the open unemployment will be resolved in the coming years. It either will increase too intense, or will keep its "crawling" character. It is also possible that the unemployment growth goes hand in hand with the positive 
changes in the GDP and the productivity in the phase of upturn. It is most likely that the Bulgarian economy faces with quite a unique situation - „recovery without new jobs“.

\section{CONCLUSION}

The problem of "underemployment“ will remain relevant. Its „accumulated“ volumes, as well as the pace of rationalization of the working time fund (resorption of the "underemployment") will have an impact on both the pace of economic recovery and the dimensions of the open unemployment. In case of a change in the distribution of the excessive labor force between the unemployed and the "underemployed", the accents of the labor policy will also change towards measures aimed at returning those who are unemployed to employment.

The negative economic dynamics, as well as other factors have a strong impact on employment and unemployment. This does not mean that the problem of internal factors of functioning of the labor market is unessential (Terziev, 2015).

\section{REFERENCE LIST}

Georgiev, Marin. (2016). Obshtestvenoto i ikonomichesko razvitie v konteksta na sotsialnite politiki. // Spisanie za nauka "Novo znanie“. Visshe Uchilishte po Agrobiznes i Razvitie na Regionite, 5, 2016, N 4, str. 26-41, ISSN 2367-4598 (Online), (Print) ISSN 1314-5703 (Георгиев, Марин. Общественото и икономическо развитие в контекста на социалните политики. // Списание за наука „Ново знание“. Висше училище по агробизнес и развитие на регионите, 5, 2016, N 4, стр. 26-41, ISSN 2367-4598 (Online), (Print) ISSN 1314-5703.

Georgiev, Marin. (2017). Sbalansirovannaya karta kak alyternativa malogo biznesa. // Innovatsionnie tehnologii v nauke novogo vrmeni, Sbornik statey Mezhdunarodnoy nauchno - prakticheskoy konferentsii 1 fevralya 2017 g., Ufa NITS AETERNA, Chasty 1, 2017, s. 43-49, ISBN 978-5-00109004-5, ISBN 978-5-00109-007-6 (Георгиев, Марин. Сбалансированная карта как альтернатива малого бизнеса. // Инновационніе технологии в науке нового врмени, Сборник статей Международной научно - практической конференции 1 февраля 2017 г., Уфра НИЦ АЭТЕРНА, Часть 1, 2017, с. 43-49, ISBN 978-5-00109-004-5, ISBN 978-5-00109-007-6).

Georgiev, Marin. (2017a). Impacts of active social programs on labor market. // Mezhdunarodnayy nauchnayy zhurnal „Innovatsionnaya nauka“. NITS Aeterna, N 02-1, 2017, pp. 139-143, ISSN 24106070 (Georgiev, Marin. Impacts of active social programs on labor market. // Международный научный журнал „Инновационная наука“. НИЦ Аэтерна, N 02-1, 2017, pp. 139-143, ISSN 24106070).

Terziev, V., Kanev, D. (2019). Modern developments in behavioral economics. // Smart Technologies and Innovations in Design for Control of Technological Processes and Objects: Economy and Production Proceeding of the International Science and Technology Conference "FarEastCon-2018" Volume 138, October 2-4, 2018, Vladivostok, Russian Federation, pp. 10-23, 2019, (Print) ISBN978-3-030-15576-6, (Online) ISBN978-3-030-15577-3.

Terziev, Venelin. (2019a). Provision of integrated employment and social assistance services in Bulgaria. // Smart Technologies and Innovations in Design for Control of Technological Processes and Objects: Economy and Production Proceeding of the International Science and Technology Conference „FarEastCon-2018“ Volume 138, October 2-4, 2018, Vladivostok, Russian Federation, pp. 24-39, 2019, (Print) ISBN978-3-030-15576-6, (Online) ISBN978-3-030-15577-3.

Terziev, Venelin. (2019b). Problems of control in the social sphere. // INTCESS 2019- 6th International Conference on Education and Social Sciences, 4-6 February, 2019, Dubai, International Organization Center of Academic Research, Istanbul, Turkey, pp. 577-593, ISBN: 978-605-82433-5-4.

Terziev, Venelin. (2019c). The criterion "competence" in the economic sector. // INTCESS 2019-6th International Conference on Education and Social Sciences, 4-6 February, 2019, Dubai, International Organization Center of Academic Research, Istanbul, Turkey, pp. 1241-1247, ISBN: 978-605-824335-4.

Terziev, Venelin. (2019d). Social policy and labor market development in Bulgarian transition period. // 
IJASOS- International E-Journal of Advances in Social Sciences, Vol. V, Issue 14, August 2019

INTCESS 2019- 6th International Conference on Education and Social Sciences, 4-6 February, 2019, Dubai, International Organization Center of Academic Research, Istanbul, Turkey, pp. 703-714, ISBN: 978-605-82433-5-4.

Terziev, Venelin. (2019e). Theoretical basis of development of labor market and social policy in the republic of Bulgaria. // INTCESS 2019-6th International Conference on Education and Social Sciences, 4-6 February, 2019, Dubai, International Organization Center of Academic Research, Istanbul, Turkey, pp. 715-726, ISBN: 978-605-82433-5-4.

Terziev, Venelin. (2019f). The problem of social efficiency- Indicators for social efficiency. // INTCESS 2019$6^{\text {th }}$ International Conference on Education and Social Sciences, 4-6 February, 2019, Dubai, International Organization Center of Academic Research, Istanbul, Turkey, pp. 669-678, ISBN: 978605-82433-5-4.

Terziev, Venelin. (2019g). Experiencing social policy development and efficiency measurment. // INTCESS 2019- $6^{\text {th }}$ International Conference on Education and Social Sciences, 4-6 February, 2019, Dubai, International Organization Center of Academic Research, Istanbul, Turkey, pp. 679-686, ISBN: 978605-82433-5-4.

Terziev, Venelin. (2019h). Efficiency and assessment of social technology. // INTCESS 2019- $6^{\text {th }}$ International Conference on Education and Social Sciences, 4-6 February, 2019, Dubai, International Organization Center of Academic Research, Istanbul, Turkey, pp. 687-694, ISBN: 978-605-82433-5-4.

Terziev, Venelin. (2019i). Conceptual framework of social adaptation. // INTCESS 2019- $6^{\text {th }}$ International Conference on Education and Social Sciences, 4-6 February, 2019, Dubai, International Organization Center of Academic Research, Istanbul, Turkey, pp. 494-503, ISBN: 978-605-82433-5-4.

Terziev, Venelin. (2019j). The dependence social adaptation- socialization. // INTCESS 2019- 6th International Conference on Education and Social Sciences, 4-6 February, 2019, Dubai, International Organization Center of Academic Research, Istanbul, Turkey, pp. 478-485, ISBN: 978-605-82433-5-4.

Terziev, Venelin. (2019k). Social activity and human resources as social development factors. // INTCESS 2019- 6th International Conference on Education and Social Sciences, 4-6 February, 2019, Dubai, International Organization Center of Academic Research, Istanbul, Turkey, pp. 546-553, ISBN: 978605-82433-5-4.

Terziev, Venelin. (2018). The active model of a social programme and its strategic advantage . // ADVED 2018- $4^{\text {th }}$ International Conference on Advances in Education and Social Sciences Abstracts \& Proceedings, 15-17 October 2018- Istanbul, Turkey, International Organization Center of Academic Research, www.ocerints.org, Istanbul, Turkey, 2018, pp. 189-203, ISBN: 978-605-82433-4-7.

Terziev, Venelin. (2018a). Active social programs development in Bulgaria: contemporary challenges and social management instruments. // ADVED 2018- $4^{\text {th }}$ International Conference on Advances in Education and Social Sciences Abstracts \& Proceedings, 15-17 October 2018- Istanbul, Turkey, International Organization Center of Academic Research, www.ocerints.org, Istanbul, Turkey, 2018, pp. 149-163, ISBN: 978-605-82433-4-7.

Terziev, Venelin. (2018b). Social assistance services and integrated employment in Bulgaria. // ADVED 2018- $4^{\text {th }}$ International Conference on Advances in Education and Social Sciences Abstracts \& Proceedings, 15-17 October 2018- Istanbul, Turkey, International Organization Center of Academic Research, www.ocerints.org, Istanbul, Turkey, 2018, pp. 164-177, ISBN: 978-605-82433-4-7.

Terziev, Venelin. (2018c). Impact of the labor market policies for ensuring employment. // ADVED 2018- $4^{\text {th }}$ International Conference on Advances in Education and Social Sciences Abstracts \& Proceedings, 1517 October 2018- Istanbul, Turkey, International Organization Center of Academic Research, www.ocerints.org, Istanbul, Turkey, 2018, pp. 178-188, ISBN: 978-605-82433-4-7.

Terziev, Venelin. (2018d). Importance of human resources to social development. // ADVED 2018- $4^{\text {th }}$ International Conference on Advances in Education and Social Sciences Abstracts \& Proceedings, 1517 October 2018- Istanbul, Turkey, International Organization Center of Academic Research, www.ocerints.org, Istanbul, Turkey, 2018, pp. 204-212, ISBN: 978-605-82433-4-7.

Terziev, V., Georgiev, M. (2018e). A strategic framework for the development of social entrepreneurship in Bulgaria. // Knowledge - International Journal, August 2018, Institute of Knowledge Management, Skopje, Macedonia, 25, 2018, N 1, pp. 23-34, ISSN 1857-923X (for e-version), ISSN 2545 - 4439 (for printed version). 
Terziev, V., Georgiev, M. (2018f). Support for the development of social entrepreneurship in Bulgaria. // Knowledge - International Journal, September, 2018, Institute of Knowledge Management, Skopje, Macedonia, 26, 2018, N1, pp.57-74, ISSN 1857-923X (for e-version), ISSN 2545 - 4439 (for printed version).

Terziev, V., E., Arabska. (2014). Assessment of active social policies' impacts on labor market in the Republic of Bulgaria. Kolektivnaya monografiya "Sotsialyno-ekonomicheskie i pravovay razvitiya ekonomiki“, Ufa, Aeterna. Rossiya, 2014. ISBN 978-5-906769-97-8, str. 3-57 (Terziev, V., E. Arabska. (2014). Assessment of active social policies' impacts on labor market in the Republic of Bulgaria. Колективная монография „Социально-экономические и правовы развития экономики“, Уфа, Аэтерна. Россия, 2014. ISBN 978-5-906769-97-8, стр. 3-57).

Terziev, Venelin. (2015). Impact of active social policies and programs in the period of active economic transformations in Bulgaria, „East West”Association for Advanced Studies and Higher Education, Vienna, 2015, ISBN 78-3-903063-44-0, 434 p.

Terziev, Venelin. (2015a). Assessment of active social policies impact of social policies on transformation processes in bulgarian economy, Moscow, 2015, Publisher „Перо“, 110 p.

Terziev, Venelin. (2015b). Opportunities for improving the efficiency of the social adaptation of servicemen discharged from military service in Bulgaria:- Novosibirsk: Publisher CRNS, 2015. ISBN 978-5-00068402-3, $270 \mathrm{p}$.

Terziev, V., E., Arabska. (2016a). Effektivnoe vliyanie na raynok truda posredstvom uluchsheniya realizatsii sotsialynoy politiki. Novosibirsk: Izdatelystvo TSRNS, 2016. ISBN 978-5-00068-496-2, 312 str (Терзиев, В., Е. Арабска. (2016а). Эфрфективное влияние на рынок труда посредством улучшения реализации социальной политики. Новосибирск: Издательство ЦРНС, 2016. ISBN 978-5-00068-496-2, 312 стр). 